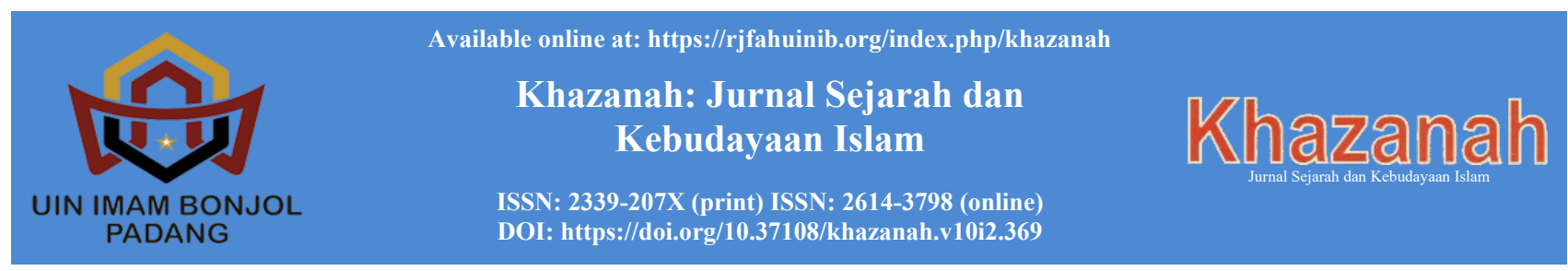

\title{
Penerimaan dan Penolakan Islam Nusantara di Kalangan Ulama Kota Palembang
}

\author{
Muhamad Harun \\ UIN Raden Fatah Palembang \\ Email: muhamadharun@ radenfatah.ac.id
}

\begin{abstract}
This article takes a focus on the acceptance and acceptance of Nusantara Islam among the Ulama of Palembang City. The background of this article is the socio-religious phenomenon seen in the Ulama of Palembang City showing different variants and expressions in addressing the term of Islam in Nusantara. A qualitative descriptive approach is used to answer the questions raised in this article. First, what is the motive for the rejection of Nusantara Islam among the ulama in Palembang City, and second, what is the motive for the acceptance of Nusantara Islam among the ulama in Palembang City. The author found that knowledge, experience and interests were motives for objections to Nusantara Islam among the old Palembang. Meanwhile, the motives for acceptance of Nusantra Islam among the Palembang Ulama include incentives, group solidarity, learning and compulsion.
\end{abstract}

Keywords: Acceptance, Rejection, Nusantara Islam, Ulama, Palembang.

\begin{abstract}
Abstrak
Artikel ini mengambil fosus pada penerimaan dan penolakan Islam Nusantara dikalangan Ulama Kota Palembang. Latar belakang artikel ini adalah fenomena sosial keagamaan yang terlihat pada kalangan Ulama Kota Palembang menunjukkan varian dan ekspresi yang berbeda dalam menyikapi terma Islam Nusantara. Pendekatan deskriptif kualitatif digunakan untuk menjawab dua pertanyaan yang diajukan pada artikel ini. Pertama bagaimana motif penolakan Islam Nusantara dikalangan ulama Kota Palembang, dan Kedua bagaimana motif penerimaan Islam Nusantara dikalangan ulama Kota Palembang. Penulis menemukan bahwa pengetahuan, pengalaman dan kepentingan adalah motif penolakan terhadap Islam Nusantara dikalangan lama Palembang. Sedangkan motif penerimaan terhadap Islam Nusantra di kalangan Ulama Palembang meliputi insentif, solidaritas kelompok, belajar dan keterpaksaan.
\end{abstract}

Kata Kunci: Penerimaan, Penolakan, Islam Nusantara, Ulama, Palembang.

\section{PENDAHULUAN}

Islam Nusantara sebagai sebuah tema booming dibincangkan oleh masyarakat Indonesia belakangan ini. Terutama sejak pencanangan Islam Nusantara oleh Muktamar Nahdlatul Ulama ke 33 di Jombang Jawa Timur. Ditemukan dua reaksi terhadap Islam Nusantara. Kelompok pertama adalah kelompok yang sepakat dan menerima. Dan kelompok kedua adalah kelompok yang menolak atau menentang.

Resistensi atau penolakan pada perubahan umumnya akan terjadi ketika ada sesuatu yang mengancam nilai. Ancaman tersebut dapat saja riel terjadi atau sebenarnya hanya suatu persepsi yang menggambarkan ketakutan individu atau kelompok saja. Dengan kata lain, ancaman perubahan tersebut bisa saja muncul dari pemahaman yang memang benar atas perubahan yang terjadi atau sebaliknya karena ketidakpahaman atas perubahan yang terjadi.

Rulianto Syahputra mengidentifikasi alasan resistensi yang ditunjukkan oleh individu dan atau kelompok, yakni 1) takut terhadap kemungkinan yang tidak diketahui; 2) takut akan kegagalan; 3) tidak sepakat dengan kebutuhan akan perubahan; 4) takut kehilangan sesuatu yang bernilai baginya; 5) enggak meninggalkan wilayah yang sudah nyaman; 6) keyakinan yang salah; 7) ketidakpahaman dan 
ketiadaan kepercayaan; dan 8) ketidakberdayaan.

Fenomena kelompok penolak dan penerima Islam Nusantara juga Nampak pada kelompok ulama Kota Palembang. Beragam ekspresi yang dinampakkan oleh kedua kelompok ini yang neunjukkan adanya pertentangan diantara keduanya. Sebagai ekses dari pertentangan tersebut adalah adanya pertentangan dikalangan gressroot. Oleh karenanya kemudian bermunculan kelompok yang meneguhkan dan saling klaim dengan argumentasi masing-masing.

Berangkat dari fenomena tersebut, tulisan ini akan menunjukkan beberapa aspek yang menjadi argument penolakan dan penerimaan serta latar belakang yang menjadi argument kedua kelompok tersebut sehingga kemudian terjadi pertentangan diantara keduanya. Secara berurut, akan dikemukakan motif keduanya melakukan penolakan dan sekaligus penerimaan Islam Nusantara di kota Palembang.

A. HASIL DAN KESIMPULAN Motif Penolakan Islam Nusantara
dikalangan Ulama Palembang Tiga aspek yang teridentifikasi sebagai motif penolakan Ulama Palembang terhadap Islam nusantara, yakni pengetahuan, pengalaman dan kepentingan. Pengetahuan bermakna pemahaman, latar belakang pendidikan dan sumber referensi bacaan kelompok penolak Islam Nusantara. Pengalaman bermakna aktivitas-aktivitas yang terkait dengan gerakan Islam Nusantara, seperti keterlibatannya dalam struktur organisasi kemasyarakatan, baik yang formal maupun informal. Sedangkan aspek kepentingan untuk menunjukkan adanya kepentingan kelompok penolak melakukan penolakan terhadap gagasan Islam Nusantara. Seperti kepentingan organisasi, kepentingan kelompok maupun kepentingan pribadi. Masing-masing akan dijelaskan sebagai berikut.

1. Pengetahuan sebagai faktor penolakan

Dalam prespektif psikologi, sikap dan perilaku seseorang tidak terlepas dari pengetahuan yang dimiliki. Sikap dan perilaku seseorang termasuk muslim biasa atau tokoh masyarakat, ataupun tokoh agama (ulama) terhadap isu atau narasi Islam Nusantara tidak terlepas dari pengetahuan yang dimilikinya termasuk pengetahuan tentang Islam Nusantara itu sendiri. Pengetahuan merupakan hasil sebuah proses pemenuhan rasa ingin tahu, yang dilakukan seseorang terhadap obyek tertentu. Pengetahuan seseorang baik muslim biasa atau tokoh masyarakat ataupun tokoh agama (ulama) terhadap isu atau narasi Islam Nusantara dilandasi dari tingkat proses pemenuhan rasa ingin tahunya terhadap isu atau narasi Islam Nusantara tersebut.

Semakin tinggi tingkat proses pemenuhan rasa ingin tahunya seseorang baik muslim biasa atau tokoh masyarkat ataupun tokoh agama (ulama) terhadap isu atau narasi Islam Nusantara maka semakin banyak pengetahuan yang diperolehnya terhadap isu atau narasi Islam nusantra tersebut. Sebaliknya semakin rendahnya tingkat proses pemenuhan rasa ingain tahunya seseorang baik muslim biasa atau tokoh masyarakat ataupun tokoh agama (ulama) terhadap isu atau narasi Islam Nusantara maka semakin sedikit pengetahuan yang diperolehnya terhadap isu atau narasi IslamNusantara tersebut.

Pengetahuan atau kognisi merupukan sesuatu yang sangat penting untuk terbentuknya sikap atau tindakan seseorang. Sikap atau tindakan seseorang baik muslim biasa atau tokoh masyarakat ataupun tokoh agama (ulama) dalam menyikapi isu atau narasi Islam Nusantara dilandasi dari banyak atau sedikitnya pengetahuan atau koginisi yang dimilikinya. Sedikit pengetahuan atau kognisi yang dimiliki muslim biasa atau tokoh masyarakat ataupun tokoh agama (ulama) terhadap isu atau narasi Islam Nusantara maka sikapnya akan cenderung kepada menolaknya. Dan sebaliknya semakin banyak pengetahuan yang dimiliki seseorang baik muslim biasa, tokoh masyarakat ataupun tokoh agama (ulama) maka sikapnya akan lebih menerima atau merespon dengan baik.

Pengetahuan atau paradigma seseorang baik muslim biasa, tokoh masyarakat ataupun tokoh agama (ulama) terhadap isu atau narasi Islam Nusantara diperoleh dari proses nalar dan rasa dalam memahami aspek-aspek Islam Nusantara semisalnya; pemikiran, gerakan dan amaliyahnya Islam Nusantara secara sintesis, komparatif dan evaluatif. Semakin besar seseorang tersebut membangun nalar dan rasanya dalam menyikapi pemikiran, gerakan dan amaliyah Islam Nusantara secara sintesis, komparatif dan evualitf maka akan semakin kaya pengetahuannya tentang Islam Nusantara tersebut. Dan sebaliknya semakin kecil seseorang tersebut baik muslim biasa, tokoh masyarakat ataupun tokoh agama (ulama) membangun nalar dan rasa memahami pemikiran, gerakan dan amaliyah Islam 
Nusantara tersebut maka semakin sedikitnya pengetahuan terhadap Islam nusantara tersebut.

Pengetahuan-pengetahuan tersebut kemudian diolah didalam diri dan akan digunakan untuk memecahkan proses yang dilalui diantaranya dalam menentukan sebuah sikap. Banyak atau sedikitnya pengetahuan seseorang baik muslim biasa, tokoh masyarakat ataupun tokoh agama tentang isu atau nasakah ataupun aspek-aspek antara lain pemikiran, gerakan islam dan amaliyah Islam Nusantara yang kemudian diolah pada dirinya. Olahan dari pengetahuan-pengetahuan tentang Islam Nusantara yang akan digunakan seseorang untuk memecahkan proses yang dilalui, dalam hal ini menentukan sikapnya terhadap isu atau naskah Islam Nusantara.

Dengan kata lain sikap seseorang terhadap sesuatu bisa dipengaruhi oleh ragam tingkat pengetahuan yang dilaluinya. Sikap seseorang baik muslim biasa, tokoh masyarakat ataupun tokoh agama (ulama) terhadap Islam Nusantara bisa dipengaruhi oleh ragam tingkat pegetahuan yang dilaluinya. Walaupun sikap belum tentu menjadi sebuah tindakan. Karena sikap pada dasarnya kesiapan reaksi terhadap obyek tertentu sebagai sesuatu penghayatan terhadap obyek yang dihadapi. Kesiapan reaksi seseorang tersebut terhadap Islam Nusantara merupakan hasil penghayatannya terhadap isu atau naskah Islam Nusantara yang dihadapinya.

Sikap pada dasarnya bisa dibedakan beberapa tingkatan yaitu; menerima, merespon, menghargai, dan bertanggung jawab. Sikap seseorang baik muslim biasa, tokoh masyarakat ataupun tokoh agama (ulama) dalam menyikapi isu atau naskah Islam Nusantara berbagai macam sikap yaitu sikap menerima, merespon, menghargai dan bertanggung jawab terhadap Islam Nusantara tersebut.

Tingkatan sikap seseorang terhadap obyek antara satu individu dengan yang lainnya berbeda-beda karena terjadinya perbedaan tingkat penghayatan terhadap obyek dan tingkat pengetahun yang dimiliknya. Tingkatan sikap seseorang baik muslim biasa, tokoh masyarakat ataupun tokoh agama (ulama) terhadap isu atau naskah Islam Nusantara berbeda-berbeda karena didasari dari tingkat penghayatan dan pengetahuannya terhadap Islam Nusantara tersebut. Semakin dalam seseorang menghayati dan juga semakin tinggi pengetahuannya terhadap isu atau naskah Islam Nusantara maka sikapnya akan semakin tinggi.

2. Pengalaman sebagai faktor resistensi

Pengalaman juga merupakan faktor penting yang mempengaruhi sikap seseorang, semakin banyak pengalaman seseorang terhadap suatu obyek atau peristiwa pada umumnya akan menentukan tingkat ketepatan dalam menentukan sikap terhdap suatu obyek atau peristiwa . Pengalaman seorang muslim biasa, tokoh masyarakat ataupun tokoh agama faktor yang mempengaruhi seseorang dalam menuntukan sikapnya untuk menerima, merespon, menghargai dan bertanggung jawab terhadap isu atau naskah IslamNusantara.

Sebaliknya seringkali ketidaktepatan dalam mengambil sikap diakibat kurangnya pengalaman seseorang terhadap suatu obyek atau peristiwa tersebut. Pengalaman seseorang terhadap suatu obyek atau peristiwa banyak dibentuk oleh kesadaran yang dimiliki dalam memaknai setiap peristiwa atau obyek yang dilaluinya. Tidak semua obyek atau peristiwa yang dilaluinya menjadi pengalaman penting dalam kehidupan seseorang. Sebab tidak semua orang memiliki kesadaran tinggi atas obyek atau peristiwa yang dilalui. Hal ini menunjukan bahwa tidak semua orang yang berada pada peristiwa atau obyek tertentu memiliki pengetahuan, sikap dan konsep pengalaman yang sama di dalam kehidupannya. Hal lain yang perlu ditekankan bahwa tingkat kesadaran terhadap pengalaman juga dipengaruhi tingkat kepentingan dimiliki sesorang.

Tingkat kesadaran akan pengalam seorang muslim, tokoh masyrakat ataupun tokoh agama (ulama) dipengaruhi juga oleh tingkat kepentingannya dalam memenuhi kebutuhannya baik kebutuhan pribadi, keluarga ataupun komunitasnya. Pengalamannya dalam memenuhi kebutuhan pribadi, keluarga atau komunitasnya mempengaruhi kesadarannya dalamberksikap merespon, menerima, menghargai atau bertanggung jawab terhadap isu atau naskah Islam Nusantara.

3. Kepentingan sebagai faktor penolakan

Kepentingan pada dasarnya merupakan fitrah kehidupan, karena manusia ditakdirkan Tuhan dilengkapi dengan hasrat kehidupan (kepentingan) semakin kompleks kehidupan manusia maka semakin banyak pula kepentingan yang harus dipenuhi. Sebaliknya semakin sederhana kehidupan seseorang maka semakin sedikit kepentingan yang harus dipenuhi. Kepentingan atau hasrat seseorang 
baik muslim biasa, tokoh masyarkat ataupun tokoh agama (ulama) sebanding setara dengan kompleks kehidupannya. Semakin banyak kompleks kehidupan seseorang baik muslim biasa, tokoh masyarakat ataupun tokoh agama (ulama) maka semakin banyak pula kepentingan yang harus dipenuhi. Sebaliknya semakin sederhana kehidupan seseorang baik muslim biasa, tokoh masyarakat ataupun tokoh agama (ulama) maka semakin sedikit kepentingan yang harus dipenuhi.

Kepentingan itu sendiri pada dasarnya bisa dibedakan menjadi beberapa kategori yaitu kepentingan individu, kepentingan sosial, dan kepentingan global. Kepentingan individu sendiri meliputi banyak aspek misalnya kepentingan memenuhi kebutuhan biologis diri sendiri, kebutuhan psikologis, kebutuhan aktualisasi dan kebutuhan spritual. Kepentingan individu seseorang baik muslim biasa, tokoh masyarakat ataupun tokoh agama (ulama) dalam memeunuhi kebutuhan biologis diri sendiri, psikologis, aktuaslisasi dan spritualnya. Kepentingan individu ulama kota palembang inilah yang memutuskan sikapnya untuk menolak isu atau naskah Islam Nusantara.

Adapun kepentingan sosial adalah sebuah hasrat memenuhi kebutuhan untuk eksistensi diri di tengah-tengah kelompok sosial atau komunitas sosial yang menjadi lingkungan kehidupannya baik bersifat lokal atau domestik ataupun lintas budaya dan geografis. Kepentingan sosial seseorang baik muslim biasa, tokoh masyarakat ataupun tokoh agama (ulama) dalam memenuhi kebutuhan untuk eksistensi diri mereka di tengah-tengah komunitas sosial mereka. Sikap komunitas mereka yang menolak isu atau naskah islam nusantara yang menyebabkan sikap ulama palembang menolak isu atau naskah Islam Nusantara demi memunuhi kebutuhan untuk eksistensi mereka di tengah-tengah komunitas atau kelompok sosial mereka ataupun organisasi mereka yangmenolak isu atau naskah Islam Nusantara.

Dalam rangka memenuhi kebutuhankebutuhan itulah kemudian kepentingankepentingan kehidupan manusia terus bertambah dan berkembang serta makin lama semakin cepat dan variatif. Selain itu perkembangan kepentingan juga mengarah kepada perkembangan aspek dan varian kultur dan struktur masyarakat dari lokal, nasional dan trans nasional bahkan lebih dari itu juga perkembangan kepentingan itu hampir meliputi seluruh aspek kehidupan, ekonomi, sosial, budaya, politik, agama, psikologi dan lain-lain.

Peneliti menemukan argumen kelompok penolak Islam Nusantara di Kota Palembang adalah disebabkan oleh faktor pengetahuan. Seperti pada pemahaman informan untuk memisahkan terma Islam dan Nusantara. Menurutnya Islam adalah Islam otentik, yakni hanya yang bersumber pada al-Qur'an dan Hadits. Karena itu, Islam adalah formal, tekstual dan sakral. Formal berarti tidak boleh ditambah, tekstual berarti mesti sesuai dengan teks dan sakral bermakna suci dan tidak boleh ada intervensi kemanusiaan terhadap ajaranajarannya. Sedangkan Nusantara adalah gagasan yang lahir dari budaya manusia. Karena itu tidak dapat dan tidak boleh disandingkan dengan Islam.

NU sebagai organisasi penyusung Islam Nusantara, amaliyah-amaliyah Islam Nusantara seperti sholawatan di Gereja, mengikuti ritual agama lain, membaca alquran dengan langgam Jawa, Sholat berbahasa Indonesia, membangun rumah dengan adat peletakkan buah pisang dan kendi air untuk makan dan minum bukan untuk pekerja, penolakan hujan turun dengan bawang cabe, bukan dengan tawassul, berdoa membaca sholawat, NKRI menjadi Negara Islam, kepemimpinan oleh wanita, kepemimpinan oleh non muslim, pengucapan, ikut merayakan kegiatan non muslim, penjagaan atau membantu dengan upah. Islam Nusantara anti arabisasi. Islam Nusantara yang dulu jangan diubah, sehingga kalau diubah nanti diklaim Islam Nusantara sesat.

Melihat fenomena-fenomena yang beredar di kalangan masyarakat dinilai membahayakan keberadaan Islam di Indonesia yang sebelumnya keberadaan Islam di Indonesia sudah sesuai dengan syariat Islam bukan adat Istiadat. Seperti halnya dalam kegiatan tasmiyah, ada sesuatu yang manis untuk dimakan, di zaman rasululloh adalah buah kurma. Lalu bayi tersebut di tahnik oleh Rasulullah SAW yang membedakan dengan kegiatan tasmiyah setelah rasul di Indoensia dengan kue manis-manis dikarenakan kesulitan untuk mendatangkan buah kurma ke Indonesia pada saat itu. Tahnik inilah merupakan imunisasi islami.

Istilah Islam Nusantara menunjukkan titik perpisahan, perbedaan antara Islam Nusantara dan Islam. Melihat sejarah dari para pengikut mazhab arba' a yang mencapai tingkat mujtahid tetaplah menyatakan minas syafi' $i$, menurut mazhab Hanafi dan yang lainnya. 
Penisbatan pemahaman mereka tetaplah keada empat mazhab, merupakan syariat Islam. Oleh sebab itu jika Islam Nusantara merupakan Islam menurut tokoh-tokoh Nusantara berarti mengubah syariat sehingga bukanlah syariat Islam melainkan Syariat Nusantara.

Keistiqomahan dalam berpegang syariat Islam menjadi kunci dalam peradaban, ketika sesuatu yang dahulu haram ketika berubah dikarenakan adat maka bukanlah hukum itu yang berubah akan tetapi adat dan istiadatnyalah yang berubah. Ilmu yang didapat dari guru-guru sebelumnya tetaplah dilanjutkan dan diajarkan kepada generasi selanjutnya. Ajaran yang disampaikan inilah sebagai warisan para guru-guru. Semisalnya pengetahuan atau ilmu tentang fahilah dzikir wirid setelah sholat yang selama ini dilakukan, pada masa saat ini dikarenakan isu yang ada bahwasanya hal seperti itu adalah bid'h atau sesat, maka sikap kita tetaplah melakukannya karena hal ini sudah dilalui oleh guru-guru sebelumnya dan memertahankan fadhilat dzikir wirid setelah sholat.

Penulis melihat, beberapa kritik yang disampaikan oleh kelompok yang kontra tidak berdasar pada gagasan dan konsep Islam Nusantara, kebanyakan kelompok kontra tidak memahami secara mendalam Islam Nusantara, kemudian membuat asumsi dan pemikiran sendiri yang tidak sesuai dengan konsep Islam Nusantara yang dimaksud oleh PBNU yang kemudian dijadikan sebagai obyek kritikan. Artinya, apa yang mereka kritik itu sebenarnya bukan Islam Nusantara, melainkan asumsi dan pikiran mereka sendiri mengenai Islam Nusantara.

Ulama-ulama Palembang yang menolak isu atau naskah Islam Nusantara didasari dari berbagai pemahaman atau pengetahuan tentang Islam Nusantara yang bersumber pengetahuannya beraneka ragam. Isu ajaran Islam Nusantara yang beredar menjadi pemahamannya antara lain; penggunaan terjemahan surat al-Fatihah dalam sholat, pemahaman lughowi atau kebahasaan Islam Nusantara dengan kaidah atau tarkib idhofah yang berfungsi sebagai kepemilikan, adat istiadat yang dikemukakan adalah adat istiadat (pernikahan, pakaian, lagu pembacaan alQuran) yang berlawanan syariat Islam, aqidah yang menyimpang yaitu menghalalkan pakaian yang tidak menutup aurat, empat pilar (prinsip) kebangsaan Negara Indonesia yang akan diubah menjadi Khilafah, toleransi dalam akidah (pengucapan hari raya kristen, bersholawat di gereja, penjagaan gereja oleh banser.

Motif Ulama Kota Palembang menerima Islam Nusantara

1. Insentif sebagai Motif Penerimaan Islam Nusantara

Pengertian Insentif secara baha arab adalah ajr dan sawab yang pada dasarnya merujuk pada pahala, upah, ganjaran, timbal balik suatu perbuatan atau pekerjaan. Kata ajr hanya digunakan dalam konteks dimana terdapat suatu akad (transaksi) atau yang serupa. Kata sawab hanya dapat digunakan untuk menggambarkan balasan atas perbuatan yang telah diperbuat. Dalam alquran, kata ajr tidak digunakan di luar konteks balasan atas ketaatan,berbeda dengan kata sawab yang dapat digunkan untuk menggambarkan balasan atas ketidakpatuhan pada perintah Allah. Kata ajr dalam alquran juga digunakan secara khas diikuti dengan beberapa kata sifat seperti 'azim, karim, kabir, hasan dan ghairu mamnun yang dalambeberapa sumber ditafsirkan maknanya sebagai surga.

Islam mengajarkan agar melakukan sesuatu, baik beribadah, bekerja sesuai profesinya, beramal baik, bermuamalah, bersosial dan sebagainya dikarenakan Allah dan Rasul-Nya pada dalam niatnya. Sebagaimana ketika berniat maka Allah akan membalas sesuai niatnya. Jika sesorang muslim biasa, tokoh masyarkat ataupun tokoh agama (ulama) berniat melakukan sesuatu dengan niat karena Allah dan Rasulnya maka Allah akan membalas apa yang ia butuhkan di dunia maupun di Akherat. Keyakinan inilah yang mendorong seseorang untuk mempertahankan, menyebarkan dan melestarikan ajaran Islam melalui isu atau naskah Islam Nusantara sebagaimana para wali songo menyebarkan Islam tanpa membumihanguskan kebudayaan yang ada.

Selain insentif merupakan pahala, insentif juga merupakan imbalan, hukuman, motivasi, rasa pengakuan, tambahan balas jasa, upah, gaji yang berbeda, untuk merangsang memperbaiki, menjaga loyalitas, mempertahankan, meningkatkan moral, kualitas maupun kuantitas, meningkatkan produktivitas, memperbaiki dan meningkatkan standar hidup dikarenakan prestasi beramal, kinerja yang tinggi, prestasi di atas prestasi standar. Hal inilah yang dilakukan oleh Para Ulama Palembang yang menerima Islam Nusantara. Menerima, menyebar luaskan, mempertahankan eksistensi Islam Nusnatara diyakini pahala yang mengalir sebagai rasa 
wujud mempertahankan warisan para walisongo dan para ulama sebagaimana yang dikatakan oleh Munir.

2. Motif Solidaritas kelompok

Secara etimologis, solidaritas adalah kesetiakawanan atau kekompakan. Solidaritas seorang muslim biasa, tokoh masyarakat ataupun tokoh agama (ulama) adalah kesetiakawanan atau kekompokan antara muslim satu dengan muslim yang lain, tokoh masyarakat dengan masyarkat serta tokoh agama (ulama) dengan ulama yang lainnya, muslim lainnya ataupun jamaahnya.semakin besar kesetiakawanan mereka atau kekompokan mereka maka semakin besar pula solidaritas mereka. Kesetiakwanan mereka dalam menerima isu atau naskah islam nusantara merupakan motif mereka dalam menerima isu atau naskah islam nusantara tersebut.

Solidaritas adalah membangun rasa kebersamaan, rasa kesatuan kepentingan, rasa simpati, sebagai salah satu anggota dari kelas sama atau dapat diartikan perasaan atau ungkapan dalam kelompok yang dibentuk oleh kepentingan bersama. Membangun rasa kebersamaan, kesatuaan kepentingan, rasa simpati antara satu muslim biasa dengan muslim lainnya, tokoh masyarakat dengan tokoh masyrakat lainnya atau dengan masyrakat itu sendiri ataupun tokoh agama (ulama) dengan ulama lainnya serta jamaahnya sendiri. Kesolidaritasan seorang muslim biasa, tokoh masyrakat ataupun tokoh agama (ulama) dalam menerima isu atau naskah Islam nusantara merupakannilai dari kebersamaan mereka, rasa kesatuan mereka ataupun rasa simpati mereka dengan satu sama lainnya.

Secara umum, solidaritas dibagi menjadi 2 yaitu: solidaritas mekanik dan solidaritas organik. Solidaritas Mekanik adalah solidaritas yang muncul pada masyarakat yang masih sederhana dan diikat oleh kesadaran kolektif serta belum mengenal adanya pembagian kerja diantara anggota kelompok. Solidaritas mekanik inilah yang lebih tepat ditujukan kepada muslim biasa, tokoh masyarakat ataupun tokoh agama (ulama) yang menerima isu atau naskah Islam Nusantara, dikarena belum adanya pembagian kerja diantara mereka bahkan jauh dari itu belum adanya organisasi atau struktur di dalam pengamalan Islam Nusantara.

Solidaritas masyarakat Islam nusantara lebih bertujuan agar lebih peka terhadap lingkungan sekitar dan terjalinnya kekompokan terhadap muslim biasa, tokoh masyarakat ataupun tokoh agama (ulama) melaui aspek-aspek Islam Nusantara berupa pemikiran, prinsip-prinsip, gerakan-gerakan dan amaliyah Islam Nusantara. Ada dua faktor yang mempengaruhi solidaritas yaitu: faktor lingkungan dan faktor keluarga. Lingkungan sekitar bisa mempengaruhi adanya rasa solidaritas seperti bagaimana cara bergaul dan berteman di dalam lingkungan. Tata cara bergaul, betoleransi berteman dan berkawan yang disajikan oleh isu atau naskah Islam Nusantara merupakan bentuk solidaritas seorang muslim biasa, tokoh masyarakat ataupun tokoh agama (ulama).

Pendidikan yang diberikan dalam keluarga sejak kecil bisa memberikan dampak positif setelah dewasa jadi pendidikan yang di berikan bagi anak-anak sangat berguna bagi perkembangannya di kehidupan yang akan datang. Solidaritas sosial memang merupakan dasar dan konsekuensi penting dari tindakan kolektif untuk sukses. Solidaritas menengahi formasi kelompok, produktivitas dan pemeliharaan. Dan solidaritas sosial dalam konteks masyarakat sangat berhubungan erat dengan karakter masyarakat.

Solidaritas merupakan aspek penting dalam berkomunitas atau bermasyarakat, dimana hubungan kerjasama dan kekompakan para anggota masyarakat menjadi sangat penting. Rasa senasib dan saling menghormati akan kepentingan bersama berjalan dengan baik, solidaritas terdiri dari kekuatan-kekuatan yang berlaku pada anggota suatu masyarakat atau kelompok untuk tinggal di dalamnya. Mereka dengan aktif untuk kelompoknya, anggota ingin menjadi bagian dari kelompok, mereka saling hidup rukun serta bersatu di dalam mengejar tujuan kelompok. Maka dari itu solidaritas sosial dalam masyarakat harus saling diperhatikan agar tercipta kerjasama yang baik demi kepentingan bersama.

3. Motif belajar sebagai faktor penerimaan

Belajar merupakan sesuatu yang berproses dan merupakan unsur yang fundamental dalam masing-masing tingkatan pendidikan. Belajar adalah suatu proses usaha yang dilakukan oleh seseorang untuk mendapatkan suatu perubahan yang baru sebagai hasil pengalamannya sendiri dalam interaksi dengan lingkungannya. Suatu proses usaha yang dilakukan seorang muslim biasa, tokoh masyarakat ataupun tokoh agama (ulama) untuk mendapatkan suatu perubahan yang baru sebagai hasil pengalamannya sendiri dalam interaksi dengan lingkungannya. Semakin rajin seorang muslim, tokoh 
masyarakat ataupun tokoh agama (ulama) belajar maka semakin banyak pula pengetahuannya tentang isu atau naskah Islam Nusantara.

Dalam hal ini, perubahan adalah sesuatu yang dilakukan secara sadar (disengaja) dan bertujuan untuk memperoleh suatu yang lebih baik dari sebelumnya. Perubahan yang dilakukan seorang muslim biasa, tokoh masyarakat

Belajar adalah suatu proses perubahan di dalam kepribadian manusia yang ditunjukkan dalam bentuk peningkatan kualitas dan kuantitas tingkah laku seperti peningkatan kecakapan, pengetahuan, sikap, kebiasaan, pemahaman, ketrampilan, daya fikir, dan kemampuan lainnya. Belajar adalah suatu proses adaptasi atau penyesuaian tingkah laku yang berlaku secara progresif. Belajar adalah suatu perubahan yang relatif dalam menetapkan tingkah laku sebagai akibat atau hasil dari pengalaman yang telah lalu. Belajar adalah perubahan tingkah laku seseorang terhadap suatu situasi tertentu yang disebabkan oleh pengalamannya yang berulang-ulang dalam situasi tersebut.

Tujuan kegiatan belajar secara umum adalah untuk memperoleh dan meningkatkan tingkah laku manusia dalam bentuk pengetahuan, keterampilan, sikap positif, dan berbagai kemampuan lainnya. Proses belajar dapat dikenali melalui beberapa karakteristiknya.

4. Motif keterpaksaan sebagai alasan penerimaan

Ide Islam Nusantara muncul dari gagasan-gagasan para intelektual kiyai-kiyai NU Jawa Timur, lalu diresmikan pada muktamar ke-33 di situbundo secara Nasional. Hasil bahsul masail inilah menginstruksikan kepada cabang-cabang dan wilayah NU untuk memberikan penjelasan secara komprehensif mengenai isu atau naskah Islam Nusantara. Pro dan kontra tentang isu atau naskah Islam Nusantara muncul di kalang non NU maupun NU itu sendiri.

Secara struktural NU, Said Agil Siroj sebagai tokoh yang yang mengusung Islam Nusantara karena jabatan Said Agil Siroj sebagai Ketua Umum Pengurus Besar NU. Secara organisasi, Organisasi Islam NU yang mengusung Islam Nusantara. Kemunculan isu atau naskah Islam Nusantara berangkat dari bermunculannya perpecahan secara politik maupun agama pada masa kholifah Abubakar Siddiq. Berkembang sampailah kekholifaan Ali bin Abi Tholib yang munculnya Islam
Syah, Islam Khowarij, Islam Jabariyah, Islam Mu'tazilah dan Islam qodariyah. Istilah-istilah tersebut melambangkan bahwasanya Islam Syiah adalah Islam ala Syiah, Islam Khowarij adalah Islam ala Khowarij, Islam Jabariyah adalah Islam ala Jabariyah, Islam Mu'tazilah adalah Islam alaMu'tailah dan Islam Qodariyah adalah Islam ala Qodaiyah.

Islam Nusantara merupakan Islam ala Nusantara yang digagas pada masa walisongo. Islam yang mengadaptasikan budaya-budaya orang-orang jawa atau wilayah penyebaran agama Islam. Budaya-budaya pada wilayahwilayah penyebaran Islam diislamisasikan oleh para walisongo sehingga kebudayaan tersebut tidak bertetangan dengan syariat Islam. Misalnya, jampi-jampian masyarakat pada saat itu belum menggunakan basmalah dan kalimat tauhid. Cara walisongo tidak membantah dari jampian itu, akan tetapi meminta kepada para penjampi agar doa atau jampian itu ditambahakn bismilah dan la ilaha illallah. Begitulah tradisi para walisongo dalam mengislamkan tradisi-tradisi yang sudah ada di Nusantara ini.

Khutbah berbahasa Indonesia adalah hasil ijtihad para walisongo dan ulama-ulama nusantara. Para anti Islam Nusantara seharusnya khutbah menggunakan bahasa Arab karena rasulullah berkhutbah bahasa arab. Hal inilah menjadi amaliyah-amaliyah dari islam Nusantara. Tradisi pada kematian yang telah mengalami islamisasi adalah tahlilan. Budaya dan tradisi kematian tetap berlangsung akan tetapi kegiatan-kegiatan yang bertentang denan syariat Islam diganti dengan amaliyah-amaliyah Islam. Kekeliruan dalam memahami Islam Nusantara yang menganggap bahwasanya Islam Nusantara adalah agama baru. Islam Nusantara adalah Islam yang tersimpan di Nusantara. Terlebih dari itu Islam Nusantara bukan agama Islam baru, aqidah baru atau fiqh baru.

Amaliyah-amaliyah Islam Nusantara tetaplah bersanad kepada Rasulullah Saw lebih menekankan menghargai budaya lokal yang tidakbertentangan dengan syariat Islam. Kekeliruan dalam memahami anti arabisasi yakni menyatakan Islam Nusantara meyalahkan ajaran Islam yaitu meyalahkan gamis atau anti gamis, menyalahkan jenggot, menyalahkan celana cingkrang dan sebagainya. Maksud dari tidak bergamis, tidak berjenggot dan tidak bercelana cingkrang bukanlah menunujukkan identitas ketidak musliman seseorang. Dalam konsep sederhana bahwasanya jadilah Islam bukan 
jadi arab. Bukan menjadikan arabisasi adalah sebagai syarat-syarat islam. ketika tidak bergamis makan bukan muslim. Ketika tidak berjenggot maka tidak muslim, dan ketika tidak bercelana jingkrak bukan muslim. Hal ini merupakan kesalahan dalam menilai isu atau naskah Islam Nusnatara adalah Islam yang menentang arabisasi. Islam Nusantara sangat menghargai islam, walaupun berkain, berbatik dan berpeci adalah orang Islam.

\section{B. KESIMPULAN}

Motif penolakan Islam Nusantara dikalangan ulama Kota Palembang disebabkan oleh tiga faktor, yakni pengetahuan, pengalaman dan kepentingan. Pada faktor pengetahuan Nampak bahwa penolak Islam Nusantara dari kalangan Ulama Kota Palembang mengalami mis persepsi terhadap gagasan dan atau konsep yang dikembangkan oleh Islam Nusantara. Demikian pula tentang pengalaman, penolakan disebabkan karena kurangnya pengalaman penolak terhadap terma Islam Nusantara. Sedangkan faktor kepentingan ada kecenderungan penolak memiliki kepentingan sebagai motif penolakan terhadap Islam Nusantara.

Sedangkan motif penerimaan terhadap Islam Nusantra di kalangan Ulama Palembang meliputi insentif, solidaritas kelompok, belajar dan keterpaksaan. Adanya insentif, rasa solidaritas kelompok, proses belajar dan keterpaksaan merupakan motif yang ditujukkkan oleh kelompok penerima Islam Nusantara dikalangan Ulama Palembang. Motif-motif ini melatarbelakangi afiliasi penerimaan kelompok terhadap Islam Nusantara dikalangan Ulama Kota Palembang

\section{DAFTAR PUSTAKA}

Ajeng Larasati, Sri Rahayu Hijrah Hati, and Anya Safira, "Religiusitas Dan Pengetahuan Terhadap Sikap Dan Intensi Konsumen Muslim Untuk Membeli Produk Kosmetik Halal," Esensi: Jurnal Bisnis Dan Manajemen 8, no. 2 (2018): 105-114.

Ricky Arnold Nggili, Belajar Any Where (GUEPEDIA, 2015).

Yayat Suharyat, "Hubungan Antara Sikap, Minat Dan Perilaku Manusia," Jurnal Region 1, no. 3 (2009): 1-19.

Darmiyati Zuchdi, "Pembentukan Sikap," Cakrawala Pendidikan, 1995, 83690.

Muhammad Anas Maarif, "Internalisasi Nilai Multikulutural Dalam Mengembangkan Sikap Toleransi (Studi Di Di Pesantren
Mahasiswa Universitas Islam Malang)," Nazhruna: Jurnal Pendidikan Islam 2, no. 1 (2019): 164-189.

Agus M. Hardjana, Penghayatan Agama: Yang Otentik \& Tidak Otentik (Kanisius, 2003).

Paul Suparno, Teori Perkembangan Kognitif Jean Piaget (Kanisius, 2001).

Syed Farid Alatas, "Pengkajian Ilmu-Ilmu Sosial: Menuju Ke Pembentukan Konsep Tepat," Antropologi Indonesia, 2014.

Akhmad Sudrajat, "Teori-Teori Motivasi," Tersedia Juga Dalam Http://Akhmadsudrajat. Wordpress. Com/2008/02/06/Teori-TeoriMotivasi/[Diakses Di Bandung: 9 Oktober 2012], 2008.

Abdul Kadir, Dasar-Dasar Pendidikan (Kencana, 2015).

Suparman Abdullah, "Potensi Dan Kekuatan Modal Sosial Dalam Suatu Komunitas," SOCIUS: Jurnal Sosiologi 12, no. 1 (2016): 15-21.

Baidhawy, Pendidikan Agama Berwawasan Multikultural.

Fathor Rahman, "Konsep Kompensasi Tafsir Al Quran Dan Hadist Pendekatan Tematik," Qolamuna: Jurnal Studi Islam 2, no. 2 (2017): 233-254.

IAIN Langsa, "KONSEP REWARD AND PUNISHMENT DALAM ALQURAN (Kajian Dari Sisi Penerapan Pendidikan Moral)," n.d.

Hasbullah Hasbullah, "Rewang: Kearifan Lokal Dalam Membangun Solidaritas Dan Integrasi Sosial Masyarakat Di Desa Bukit Batu Kabupaten Bengkalis," Sosial Budaya 9, no. 2 (2012): 231-243.

Mifdal Zusron Alfaqi, "Memahami Indonesia Melalui Prespektif Nasionalisme, Politik Identitas, Serta Solidaritas," Jurnal Pendidikan Pancasila Dan Kewarganegaraan 28, no. 2 (2015).

DILA OKTARIANA, "PENGARUH BUDAYA SAKAI SAMBAYAN TERHADAP SOLIDARITAS SOSIAL (Studi Kasus Di Desa Negeri Agung, Kabupaten Waykanan)," 2016.

Abdul Mujib Abdul Mujib and Jusuf Mudzakkir Jusuf Mudzakkir, Ilmu Pendidikan Islam (Kencana Prenada Media Group, 2007).

Alfaqi, "Memahami Indonesia Melalui Prespektif Nasionalisme, Politik Identitas, Serta Solidaritas." 
Umi Hanifah, "TRANSFORMASI SOSIAL MASYARAKAT SAMIN Di BOJONEGORO (Analisis Perubahan Sosial Dalam Pembagian Kerja Dan Solidaritas Sosial Emile Durkheim)," Jurnal Sosiologi Agama 13, no. 1 (2019): 41-71.

Aliyah Farwah, "Faktor Sosial Terhadap Kesejahteraan Islami Keluarga Muslim Di Kota Surabaya," Jurnal Ekonomi Dan Bisnis Airlangga (JEBA) 23, no. 2 (2013).

Yudrik Jahja, Psikologi Perkembangan (Kencana, 2011).

Pip Jones, Pengantar Teori-Teori Sosial: Dari Fungsionalisme Hingga Post-Modernisme (Yayasan Pustaka Obor Indonesia, 2010).

Luluk Dwi Kumalasari, "MAKNA SOLIDARITAS SOSIAL DALAM TRADISI 'SEDEKAH DESA'(Studi Pada Masyarakat Desa Ngogri Megaluh Jombang)," Research Report, 2017, 1110-1123.

Ugi Nugraha, "Hubungan Persepsi, Sikap Dan Motivasi Belajar Terhadap Hasil Belajar Pada Mahasiswa Pendidikan Olahraga Dan Kesehatan Universitas Jambi.," Cerdas Sifa Pendidikan 1, no. 1 (2015).

Gina Rosarina, Ali Sudin, and Atep Sujana, "Penerapan Model Discovery Learning Untuk Meningkatkan Hasil Belajar Siswa Pada Materi Perubahan Wujud Benda," Jurnal Pena Ilmiah 1, no. 1 (2016).

LENI ASTUTI, "PENGARUH KECERDASAN SPIRITUAL, KECERDASAN INTELEKTUAL DAN KECERDASAN EMOSIONAL DENGAN PRESTASI BELAJAR PADA SISWA IPS KELAS XI DI SMA NEGERI 01PURWANEGARA KABUPATEN BANJARNEGARA" (PhD Thesis, UNIVERSITAS MUHAMMADIYAH PURWOKERTO, 2014).

JUNAIDIN JUNAIDIN, "PEMERINTAHAN ALI BIN ABI THALIB DAN PERMULAAN KONFLIK UMAT ISLAM," FiTUA: Jurnal Studi Islam 1, no. 1 (2020): 33-48.

S. Pd I. Hermawan, STUDI ISLAM NUSANTARA (YAYASAN HJ. KARTINI KUDUS, 2019).

Helmy Qadarusman and Abdul Matin Bin Salman, "EFEKTIFITAS PENGGUNAAN AYATAYAT AL-QURAN SEBAGAI RUQYAHDI RUQYAH BEKAM CENTER KLATEN" (PhD Thesis, IAIN SURAKARTA, 2017).
Moh Ali Aziz, Ilmu Dakwah: Edisi Revisi (Prenada Media, 2019).

Bobby Zulfikar Akbar, "Kontekstualisasi Hadis Tentang Anjuran Memelihara Jenggot Dan Larangan Isbal Pada Zaman Kekinian," AlDzikra: Jurnal Studi Ilmu al-Qur'an Dan al-Hadits 12, no. 2 (2018): 137-164.

https://ruliantosjahputra.blogspot.com/2014/02/resi stensi-pada-perubahan.html diakses tanggal 26 Oktober 2019.

Volume 10, Nomor 02, Edisi Juli-Desember 2020 
196 Penerimaan dan Penolakan Islam... 